Биопрепараты и биозащита

\title{
СОВМЕСТНОЕ ИСПОЛЬЗОВАНИЕ ШТАММОВ МИКРООРГАНИЗМОВ И ХИТОЗАНОВЫХ КОМПЛЕКСОВ ДЛЯ ПОВЫШЕНИЯ УРОЖАЙНОСТИ ПШЕНИЦЫ (Triticum aestivum L.)
}

\author{
Л.Е. КОЛЕСНИКОВ1, Э.В. ПОПОВА², И.И. НОВИКОВА래 Н.С. ПРИЯТКИН ${ }^{3}$, \\ М.В. АРХИПОВ 3 , Ю.Р. КОЛЕСНИКОВА ${ }^{4}$, Н.Н. ПОТРАХОВ ${ }^{5}$, В. VAN DUIJN 6 , \\ А.С. ГУСАРЕНКО 1
}

Создание эффективных и высокотехнологичных препаративных форм для микробиологической защиты растений - ключевая проблема сельскохозяйственной биотехнологии. В представленной работе нами выявлены различия в структуре урожая, интроскопических характеристиках зерна пшеницы и ее устойчивости к корневой гнили при применении полифункциональных препаратов нового поколения. Целью исследования было обоснование перспективности использования полифункциональных препаратов на основе микроорганизмов - антагонистов возбудителей болезней и хитозановых комплексов для защиты яровой мягкой пшеницы от корневой гнили и повышения урожайности, а также оценка качества зерна методами микрофокусной рентгенографии и газоразрядной визуализации. Экспериментальные исследования выполняли на яровой мягкой пшенице (Triticum aestivum L.) сорта Ленинградская 6 в 2016-2017 годах (опытное поле Всероссийского института генетических ресурсов растений им. Н.И. Вавилова). Вегетационный период 2016 года характеризовался более благоприятными погодными условиями для возделывания пшеницы, чем 2017 год (незначительное колебание температуры и существенное количество выпавших осадков). Продуктивность пшеницы оценивали по энергии прорастания семян, длине проростка, фазе развития и высоте растения, числу, массе и длине корней, числу колосков в колосе, площади флагового и предфлагового листа, массе колоса и вегетативной части. На основании достоверных положительных изменений показателей продуктивности по сравнению с контролем биопрепараты были ранжированы по биологической эффективности следующим образом: в 2016 году - Витаплан, Ж (ООО «АгроБиоТехнология», Россия) > Витаплан, Ж + Хитозан II (опытный образец, ФГБНУ ВИЗР, смесь хитозанов 50 и 100 кДа с добавлением 0,1 \% ванилина) > Гамаир, СП (ООО «АгроБиоТехнология», Россия) > Хитозан I (опытный образец, ФГБНУ ВИЗР, смесь хитозанов 50 и 100 кДа с добавлением 0,05\% салициловой кислоты) > Хитозан II; в 2017 году - Витаплан, Ж > Витаплан, СП > Витаплан, Ж + Хитозан II > Хитозан II. При совместном применении препарата Витаплан, Ж с хитозановым комплексом Хитозан II (смесь хитозанов с органическими кислотами с добавлением ванилина) в 2016 году отмечали достоверное изменение не только массы вегетативной части растения, но и массы колоса, в то время как один Хитозан II достоверно увеличивал только массу вегетативной части растений. В 2017 году в этом варианте для растений было характерно значительное увеличение площади флагового листа и массы корней - соответственно на 86,84 и 83,33\% по сравнению с контролем. В 2016 году применение Хитозана I (смесь хитозанов с органическими кислотами с добавлением салициловой кислоты) способствовало достоверному увеличению потенщиальной урожайности пшенищы на 19,0\% $(t=3,0 ; \mathrm{p}<0,05)$ по сравнению с контролем, но не было выявлено существенных различий с контролем в вариантах с биопрепаратом Витаплан, Ж, комплексом Витаплан, Ж + Хитозан II и Хитозаном II. В 2017 году наиболыший достоверный прирост урожайности 82,6 \% $(t=7,2$; p $<0,05)$, напротив, зарегистрировали в варианте Витаплан, Ж + Хитозан II. Максимальную эффективность против гельминтоспориозной корневой гнили проявляли биопрепарат Витаплан, Ж и комплекс Витаплан, Ж + Хитозан II. В варианте Витаплан, Ж + Хитозан II в 2016 году отмечалось снижение развития корневой гнили на 80 \% по сравнению с контролем, а в 2017 году симптомов развития болезни не обнаружили, что может быть обусловлено менее благоприятными для развития корневой гнили метеоусловиями 2017 года по сравнению с 2016 годом. Потенциальная урожайность пшеницы достоверно положительно коррелировала с площадыю проекции рентгенограммы, интегральной яркостью зерен и суммарной интенсивностью газоразрядного свечения. В наибольшей степени на структурно-функциональные характеристики зерна влияли Хитозан I, Хитозан II и комплекс Витаплан, Ж + Хитозан II. Возможно, эффективность изученных препаратов зависела от погодных условий, но в целом была положительной по основным указанным выше показателям. Таким образом, проведенные исследования убедительно показали перспективность использования полифункциональных препаратов, объединяющих полезные свойства штаммов микроорганизмов - антагонистов возбудителей болезней и хитозана как активатора болезнеустойчивости растений для защиты пшеницы от корневой гнили, повышения урожайности и улучшения качества зерна.

Ключевые слова: Triticum aestivum L., яровая мягкая пшеница, биопрепараты, хитоза- 
новые составы, структура урожая, корневая гниль, качество семян, микрофокусная рентгенография, газоразрядная визуализация.

Яровая пшеница - основная продовольственная культура и важный объект российского экспорта. Получение высоких устойчивых урожаев качественного зерна яровой пшеницы возможно только при выполнении ряда мероприятий, которые включают использование основных приемов почвозащитной технологии и методов повышения плодородия почвы, правильных севооборотов с достаточным насыщением чистыми парами, оптимальных для условий и задач возделывания сортов, а также соблюдение требований агротехники, соответствующих биологическим особенностям сортов культуры. Однако в настоящее время потенциал продуктивности культуры чаще всего реализуется лишь на треть, что свидетельствует о необходимости совершенствования технологий возделывания $(1,2)$.

Очевидно, что оптимизация условий для роста и развития растений на всех этапах онтогенеза - одна из важнейших задач современного растениеводства. Ее решение в значительной степени связано с разработкой технологий производства и применения экологически безопасных полифункциональных препаративных форм, способных эффективно снижать распространенность и развитие опасных болезней и повышать болезнеустойчивость растений, а также стимулировать их рост и развитие.

Создание эффективных и высокотехнологичных препаративных форм для микробиологической защиты растений - ключевая проблема сельскохозяйственной биотехнологии. К числу таких средств относятся зарегистрированные в России биопрепараты Витаплан, Алирин-Б и Гамаир, которые выпускаются в виде смачивающихся порошков, суспензионных концентратов, таблетированных и жидких форм (совместная разработка ООО «АгроБиоТехнология», г. Москва, и Всероссийского НИИ защиты растений) $(3,4)$. Биопрепараты показали высокую эффективность в борьбе с болезнями основных сельскохозяйственных культур, способствовали повышению урожайности и качества растениеводческой продукции. Кроме того, в некоторых случаях обнаружено существенное влияние интродуцированных штаммов микробов-антагонистов на видовой состав комплекса почвообитающих фитопатогенных грибов и супрессивность почвы в агробиоценозах (5).

В последние годы разработаны препараты нового поколения - индукторы болезнеустойчивости на основе хитозана, результаты применения которых широко обсуждаются (6-8). Хитозан - натуральный полимер со звеньями $\beta$-Д-глюкозамина и $\mathrm{N}$-ацетил- $\beta$-Д-глюкозамина (9), получаемый посредством деацетилирования хитина ракообразных, насекомых, грибов (10-13). Установлено положительное влияние хитозана на рост и развитие растений (14). Обработка листьев пшеницы хитозаном приводила к увеличению концентрации фенольных кислот, особенно феруловой кислоты. Хитозан оказывает стимулирующее действие на образование прекурсоров лигнина (п-кумаровая, феруловая, синаповая кислоты), а также на синтез фенольных кислот, обладающих антимикробной активностью, - бензойной, п-кумаровой, кофеиновой, протокатеховой, хлорогеновой, феруловой и галловой $(15,16)$. У растений пшеницы, обработанных хитозаном и подвергнутых стрессу засухи, по сравнению с контролем значительно возрастали индекс роста, скорость прорастания, количество влаги в зерне, длина и активность корней, изменялись физиологические показатели: активность супероксиддисмутазы, перокзидазы, каталазы, содержание малондиальдегида и хлорофилла (17). Обработка хитозаном, увеличивая содержание хлорофилла в листьях пшеницы, обусловила повышение урожая на 
13,6 \% по сравнению с контролем (17).

В России в последние годы ведутся исследования по созданию композиций на основе иммобилизации микробов-антагонистов Bacillus subtilis M-22 и Trichoderma viride Т-36 на хитин-хитозановых носителях для эффективной защиты овощных культур от почвенной фузариозной инфекции и нематод $(18,19)$. Высокий защитный эффект (до 70 \%) таких комплексных биопрепаратов обусловлен сочетанием свойств микроба-антагониста со способностью хитозана совместно с биологически активными веществами усиливать механизмы естественной устойчивости растений к патогенам. При этом наблюдается синергетический эффект компонентов композиции.

Необходимое условие получения высокого урожая пшеницы - использование при посеве качественного зерна (20). В связи с этим существует ряд стандартных тестов, регламентированных ISTA (International Seed Testing Association), а также перспективных интроскопических методов контроля качества семенного материала. Метод мягколучевой микрофокусной рентгенографии на протяжении многих лет успешно применяется как в России $(21,22)$, так и за рубежом (23-26). С его помощью можно обнаруживать различные структурные дефекты семян (трещиноватость, энзимомикозное истощение, внутреннее прорастание, скрытая заселенность вредителями, повреждение клопом вредная черепашка, механические травмы и дефектность зародыша, пустозерность). Компьютерная микротомография позволяет получить объемное изображение внутренней структуры зерновки (27) и визуализировать некоторые структурные дефекты (28).

В последние 10 лет появились данные о возможности использования метода терагерцовой визуализации для определения сортовой чистоты семян (29), качества семенного материала (30), а также сверхраннего прогнозирования лабораторной всхожести семян (31). Метод визуализации семян в терагерцовом диапазоне позволяет улавливать изменения, происходящие при прорастании, уже спустя 6 ч после их замачивания (31).

В представленной работе впервые показана эффективность использования полифункциональных препаратов на основе штаммов микроорганизмов - антагонистов возбудителей болезней и активаторов болезнеустойчивости растений - хитозановых комплексов для повышения урожайности и защиты яровой мягкой пшеницы от болезней. Определены различия в структуре урожайности пшеницы и ее устойчивости к корневой гнили при их применении, выявлено их влияние на интроскопические характеристики зерна.

Цель нашего исследования - обосновать перспективность использования полифункциональных препаратов на основе антагонистов возбудителей болезней и хитозановых комплексов для защиты яровой мягкой пшеницы от корневой гнили и повышения урожайности, а также оценить качество зерна методами микрофокусной рентгенографии и газоразрядной визуализации.

Методика. Эксперименты выполняли на растениях яровой мягкой пшеницы (Triticum aestivum L.) сорта Ленинградская 6 (к-6490; предоставлен отделом генетических ресурсов пшениц Всероссийского института генетических ресурсов растений им. Н.И. Вавилова - ВИР) в 2016-2017 годах (опытное поле ВИР). Посев проводили 7 мая на делянки площадью $1,0 \mathrm{M}^{2}$ рядовым способом, с междурядьями $15 \mathrm{~cm}$ и расстоянием в ряду 1-2 см (400 зерен/м²). Глубина заделки семян - 5-6 см.

Схема опыта в 2016 году предусматривала следующие варианты: без обработки (контроль); Гамаир, СП (ООО «АгроБиоТехнология», Россия) - стандарт; Витаплан, Ж (ООО «АгроБиоТехнология», Россия); хи- 
тозановый комплекс Хитозан I (опытный образец, ФГБНУ ВИЗР); хитозановый комплекс Хитозан II (опытный образец, ФГБНУ ВИЗР); комплекс Витаплан + Хитозан II. Гамаир, СП - фунгицид на основе штамма Bacillus subtilis M-22 (препаративная форма - смачивающийся порошок; титр жизнеспособных клеток определяли в КОЕ/г). Порошок (5 г) растворяли в 10 л воды и обрабатывали 1 т семян полусухим способом. Витаплан, Ж - культуральная жидкость штаммов B. subtilis BKM B-2604D и B. subtilis BKM B-2605D (соотношение 1:1, титр живых клеток и спор B. subtilis - $10^{10}$ KOЕ/мл). Семена (50 г) замачивали в 100 мл культуральной жидкости в течение 1 ч. В состав комплекса Хитозан I входили хитозаны с молекулярной массой 100 кДа и 50 кДа в соотношении 1:1 (в массовых частях), а также смесь янтарной и глутаминовой кислот (органические кислоты) при соотношении хитозан:органические кислоты 1:1, в которую была добавлена 0,05 \% салициловая кислота. Комплекс Хитозан II включал хитозаны 100 кДа и 50 кДа в соотношении 1:1, смесь янтарной и глутаминовой кислот при соотношении хитозан:органические кислоты 1:1 и $0,1 \%$ ванилина. Хитозаны 50 и 100 кДа получены авторами методом окислительной деструкции нитритом натрия в кислой среде из хитозана с молекулярной массой 150 кДа и степенью деацетилирования 85 \% («Биопрогресс», Россия). Обработку семян обоими комплексами проводили полусухим способом из расхода 80 г в 10 л воды на 1 т семян. При обработке комплексом Витаплан, Ж + Хитозан II в культуральную жидкость биопрепарата Витаплан Ж вводили Хитозан II до концентрации 0,1 \% (50 г семян замачивали в 100 мл культуральной жидкости в течение 1 ч). Обработку вегетирующих растений в 2016 году проводили 24 июня, 9 и 19 июля. Стандарт Гамаир, СП использовали из расчета 10 г препарата на 300 л воды. Витаплан, Ж разводили водой в 10 раз, расход жидкости -100 мл/м². При опрыскивании растений водными растворами препаратов Хитозан I и Хитозан II расчет концентрации $(0,1 \%)$ вели по главному компоненту хитозану; расход жидкости - 100 мл/м². В варианте с комплексом Хитозан II вместо ванилина добавляли индолилуксусную кислоту в концентрации $0,0015 \%$ как основной гормон роста растений. При использовании комплекса Витаплан, Ж + Хитозан II культуральную жидкость с титром клеток $10^{10} \mathrm{KOE} /$ мл разводили водой в 10 раз; расход жидкости -100 мл/м².

В 2017 году опыт включал пять вариантов: без обработки (контроль); Витаплан, СП - стандарт, из расчета 10 г препарата на 300 л воды; Витаплан, Ж; хитозановый комплекс Хитозан II; комплекс Витаплан, Ж + Хитозан II. Осуществляли обработку семян пшеницы перед посевом и опрыскивание препаратами вегетирующих растений по схеме, аналогичной примененной в 2016 году.

В период кущения пшеницы определяли число, длину и массу корней (главный зародышевой корень, зародышевые и колеоптильные корни). Учитывали число и длину узловых корней. В каждом варианте опыта оценивали по 20 растений в 2-кратной повторности. Фазы онтогенеза пшеницы учитывали по Eucarpia (EC)-scale (Zadoks scale).

При изучении структуры урожая анализировали данные по продуктивной и общей кустистости, высоте растений, длине колоса, числу колосков в колосе, массе колоса. Определяли массу вегетативной части растений, площадь флаговых и предфлаговых листьев в соответствии с методическими указаниями (32).

Потенциальную урожайность пшеницы $\mathrm{Y}_{\mathrm{p}}$ (т/га) рассчитывали по продуктивной кустистости и числу растений на $1 \mathrm{M}^{2}: \mathrm{Y}_{\mathrm{p}}=\mathrm{M}_{\mathrm{K}} \mathrm{K}_{\Pi} \mathrm{P}_{\Pi} \times 10000$, где $\mathrm{M}_{\mathrm{K}}-$ масса зерен в колосе одного растения, т; $\mathrm{K}_{\Pi}-$ продуктивная ку- 
стистость образца (число стеблей с колосьями у одного растения, шт.); $\mathrm{P}_{\text {п }}-$ плотность посева, число растений на $1 \mathrm{~m}^{2}$.

Степень поражения растений корневой гнилью определяли в полевых условиях в фазу кущения пшеницы (15 июля 2016 года) по общепринятой шкале: 0 - эпикотиль без поражения, 1 - единичные пятна на эпикотиле, 2 - сильное поражение, 3 - сильное поражение, растение погибло. В каждом варианте опыта изучали по 20 растений в 2-кратной повторности.

Развитие корневой гнили по вариантам опыта оценивали по средневзвешенной величине степени поражения растений Рб (33):

$$
P б=\frac{\Sigma(\mathrm{a} b) 100}{\mathrm{AK}},
$$

где $a-$ число растений с одинаковыми признаками поражения, $b-$ coответствующий балл, А - число растений в учете (здоровых и больных), K - высший балл учетной шкалы.

В 2016 году также провели лабораторный опыт по определению энергии прорастания зерен (\%) при обработке указанными биопрепаратами и хитозановыми комплексами (контроль - без обработки) (начало опыта 30 мая). В каждом варианте в чашках Петри проанализировали по 100 зерен (1 июня), длину проростков измеряли через 1 сут после помещения материала во влажную камеру (2 июня) и на следующий день (3 июня).

Для оценки интроскопических характеристик зерна использовали методы микрофокусной рентгенографии и газоразрядной визуализации (ГРВ). При рентген-съемке зерен пшеницы на серийной передвижной рентгенодиагностической установке ПРДУ-02 (ЗАО «ЭЛТЕХ-Мед», Россия) коэффициент увеличения составил $\times 3,0$. Анализ цифровых рентгеновских изображений зерен пшеницы выполняли с помощью программного обеспечения Агрус-Био (ООО «АргусСофт», Россия). На рентген-проекции зерновки оценивали площадь $\left(\mathrm{cm}^{2}\right)$, периметр (см), длину (см), ширину (см), округлость (отн. ед.), удлиненность (отн. ед.), изрезанность (отн. ед.), среднюю яркость (ед. яркости), среднеквадратическое отклонение яркости (ед. яркости), оптическую плотность (отн. ед.) и интегральную оптическую плотность (отн. ед.). Газоразрядную визуализацию (электрофотография с регистрацией и количественной оценкой характеристик коронного разряда, возникающего при помещении семени в электромагнитное поле высокой напряженности) выполняли на серийном аппарате ГРВ-Камера с программным обеспечением для анализа цифровых газоразрядных изображений ГРВ Научная лаборатория (ООО «Биотехпрогресс», Россия). Проанализировали следующие параметры цифровых газоразрядных изображений зерен: площадь свечения (пиксели), суммарную интенсивность свечения (отн. ед.), коэффициент формы (отн. ед.), средний радиус изолинии (пиксели), нормализованное среднеквадратическое отклонение радиуса изолинии (пиксели), длину изолинии (пиксели), энтропию, рассчитанную по изолинии (отн. ед.), фрактальность, рассчитанную по изолинии (отн. ед.).

Статистический анализ полученных результатов проводили в программах SPSS 21.0, Statistica 6.0, Excel 2016 (34). При расчетах использовали методы параметрической (на основе средних $M$ и их стандартных ошибок $\pm \mathrm{SEM}, 95 \%$ доверительных интервалов и $t$-критерия Стьюдента) и многомерной статистики (кластерный и факторный анализ).

Результаты. Погодные условия вегетационного периода 2016 года в Ленинградской области характеризовались повышенными значениями среднемесячной температуры: в мае превышение нормы составило $3,4{ }^{\circ} \mathrm{C}$, в июне-августе - в пределах $1{ }^{\circ} \mathrm{C}$; сумма выпавших осадков в мае составила 
Показатели продуктивности яровой мягкой пшенищы (Triticum aestivum L.) сорта Ленинградская 6 под влиянием полифункциональных препаратов на основе штаммов микроорганизмов-антагонистов и хитозановых комплексов ( $\pm \pm \mathrm{SEM}$, г. Санкт-Петербург-Пушкин, 2016 год)

\begin{tabular}{|c|c|c|c|c|c|c|c|c|c|c|c|c|c|c|}
\hline Вариант опыта & $Э_{3,}, \%$ & $\mathrm{~L}_{\mathrm{p},}, \mathrm{MM}$ & $\Phi$, балл & $\mathrm{h}, \mathrm{cm}$ & $\mathrm{N}_{\mathrm{K} .}$, шт. & $\mathrm{L}_{\mathrm{K} .}, \mathrm{MM}$ & $\mathrm{M}_{\mathrm{K} .}, \Gamma$ & $\mathrm{N}_{\text {V.K. }}$, Шт. & $\mathrm{L}_{\text {Y.K. }}, \mathrm{MM}$ & $\mathrm{N}_{\text {K.K. }}$, ШТ. & $\mathrm{S}_{\text {фл. }}, \mathrm{cm}^{2}$ & $\mathrm{~S}_{\text {прфл. }}, \mathrm{cm}^{2}$ & $\mathrm{M}_{\mathrm{K} . \Pi .}, \Gamma$ & $\mathrm{M}_{\text {В.ч., }} \Gamma$ \\
\hline Контроль (вода) & 71,4 & $9,6 \pm 2,0$ & $62,5 \pm 1,6$ & $81,3 \pm 3,8$ & $4,4 \pm 0,6$ & $61,0 \pm 5,4$ & $0,3 \pm 0,1$ & $6,5 \pm 0,7$ & $56,4 \pm 4,1$ & $12,8 \pm 0,6$ & $7,1 \pm 0,4$ & $7,6 \pm 0,5$ & $0,4 \pm 0,1$ & $2,0 \pm 0,2$ \\
\hline Гамаир, СП & 96,5 & $16,6 \pm 1,9 *$ & $64,5 \pm 0,6$ & $86,6 \pm 3,0$ & $6,4 \pm 0,4^{*}$ & $73,6 \pm 4,7$ & $0,3 \pm 0,05$ & $5,9 \pm 0,7$ & $41,2 \pm 4,7 *$ & $13,5 \pm 0,6$ & $7,9 \pm 0,6$ & $9,2 \pm 0,4^{*}$ & $0,5 \pm 0,1$ & $2,4 \pm 0,2$ \\
\hline Витаплан, Ж & 86,8 & $16,2 \pm 1,9^{*}$ & $67,8 \pm 1,1^{*}$ & $90,1 \pm 2,5^{*}$ & $6,5 \pm 0,5^{*}$ & $76,8 \pm 4,8^{*}$ & $0,3 \pm 0,04$ & $7,0 \pm 0,5$ & $54,6 \pm 3,9$ & $14,2 \pm 0,5$ & $6,4 \pm 0,6$ & $8,4 \pm 0,8$ & $0,5 \pm 0,03$ & $2,3 \pm 0,1$ \\
\hline Витаплан, Ж + Хитозан II & 74,4 & $19,6 \pm 2,0$ & $69,4 \pm 0,8^{*}$ & $98,6 \pm 2,8$ & $5,9 \pm 0,5^{*}$ & $62,1 \pm 3,8$ & $0,4 \pm 0,02$ & $7,4 \pm 0,7$ & $48,0 \pm 4,8$ & $13,9 \pm 0,6$ & $8,1 \pm 0,4^{*}$ & $7,6 \pm 0,5$ & $0,6 \pm 0,03^{*}$ & $2,5 \pm 0,2^{*}$ \\
\hline Хитозан I & 82,4 & $9,1 \pm 1,6$ & $67,9 \pm 0,9^{*}$ & $87,9 \pm 2,6$ & $6,2 \pm 0,5^{*}$ & $69,1 \pm 3,4$ & $0,3 \pm 0,05$ & $6,9 \pm 0,7$ & $53,3 \pm 3,9$ & $14,3 \pm 0,5$ & $7,5 \pm 0,7$ & $8,0 \pm 0,5$ & $0,6 \pm 0,1$ & $2,5 \pm 0,3$ \\
\hline Хитозан II & 79,8 & $8,9 \pm 1,2$ & $60,7 \pm 2,2$ & $83,6 \pm 3,6$ & $4,6 \pm 0,5$ & $70,4 \pm 5,0$ & $0,4 \pm 0,1$ & $7,7 \pm 0,7$ & $66,1 \pm 5,1$ & $12,2 \pm 0,8$ & $7,9 \pm 0,7$ & $6,6 \pm 1,1$ & $0,6 \pm 0,1$ & $2,7 \pm 0,3$ \\
\hline $\begin{array}{l}\text { П р и м е ч а н и е. } Э_{3 .}- \\
\mathrm{N}_{\text {у.к. }}-\text { число узловых к } \\
\mathrm{M}_{\text {в.ч. }}-\text { масса вегетативн } \\
\text { * Различия с контролем }\end{array}$ & Ти. & & & & & & & & & & , & & & \\
\hline
\end{tabular}


$64 \%$ от нормы, однако в летние месяцы ее значения существенно превысили норму (в июне $-137 \%$, в июле $-191 \%$, в августе $-227 \%$ от нормы). В мае-июле 2017 года снижение среднемесячной температуры находилось в пределах $2,5^{\circ} \mathrm{C}$ от нормы; осадки в мае составили $29 \%$, что значительно ниже нормы; летом этот показатель повысился и достиг в июне $115 \%$, в июле $155 \%$, августе $175 \%$ от нормы. Таким образом, вегетационный период 2016 года характеризовался более благоприятными погодными условиями для роста растений, учитывая незначительное колебание температуры и сушественное количество выпавших осадков.

На первом этапе исследований изучали влияние биопрепаратов и хитозановых комплексов на показатели продуктивности и потенциальную урожайность яровой мягкой пшеницы (табл.). В 2016 году (в условиях повышенных среднемесячных температур и существенного превышения нормы выпавших осадков в летние месяцы) в варианте с обработкой семян препаратом Гамаир, СП энергия прорастания была на $25 \%$ выше, чем в контроле, и достигла максимального значения - 96,5 \%. Достоверное $(\mathrm{p}<0,05)$ увеличение длины ростка зафиксировали в вариантах с применением препаратов Гамаир, СП (на 73,7 \%) и Витаплан, Ж (на 69,5 \%).
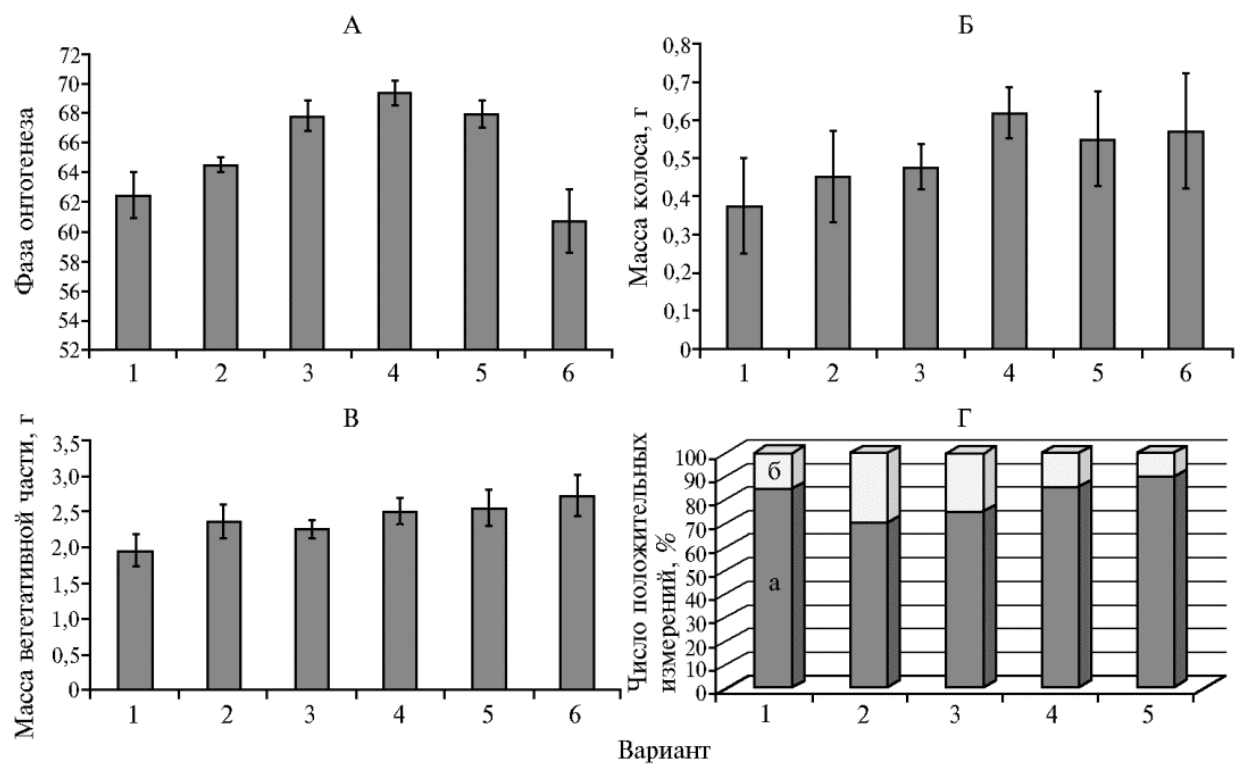

Рис. 1. Показатели продуктивности у яровой мягкой пшеницы (Triticum aestivum L.) сорта Ленинградская 6 под влиянием полифункциональных препаратов на основе штаммов микроорганизмов-антагонистов и хитозановых комплексов: А - фаза онтогенеза по шкале Eucarpia (EC)scale, Б - масса колоса, В - масса вегетативной части, Г - комплекс показателей (а - число положительных измерений, б - число достоверных положительных измерений); 1 контроль (вода), 2 - Гамаир, СП, 3 - Витаплан, Ж, 4 - Витаплан, Ж + Хитозан II, 5 Хитозан I, 6 - Хитозан II (г. Санкт-Петербург-Пушкин, опытное поле, 2016 год).

По сравнению с контролем наибольшей скоростью роста по фазам онтогенеза, определенным по шкале Eucarpia (EC)-scale, на стадии колошения выделялись образцы, обработанные препаратом Витаплан, Ж совместно с комплексом Хитозан II (достоверное увеличение балла на $11 \%$, $t=7,8, \mathrm{p}<0,05)$. Максимальную интенсивность развития пшеницы обеспечивала обработка препаратами Витаплан, Ж и Хитозан I (рис. 1, А). Достоверное $(\mathrm{p}<0,05)$ увеличение высоты растений на $10,8 \%$ в стадии колошения отмечали в варианте с обработкой семян Витапланом, СП.

Во всех вариантах опыта с применением препаратов увеличивалось число корней, отходящих от эпикотиля (главный зародышевой корень, 
зародышевые и колеоптильные корни) по сравнению с контролем. Использование препарата Гамаир, СП обусловливало достоверный рост числа корней - на 44,7 \% $(t=2,7, \mathrm{p}<0,05)$, Витаплан, Ж - на 46,3\% $(t=2,6$, $\mathrm{p}<0,05)$, Витаплан, Ж совместно с Хитозаном II - на $32,3 \%(t=2,7$, $\mathrm{p}<0,05)$, Хитозан I - на $32,3 \%(t=2,3, \mathrm{p}<0,05)$. Использование хитинового комплекса Хитозан II не оказало существенного влияния на этот показатель (см. табл.).

Практически во всех вариантах опыта (Витаплан, Ж, Витаплан, Ж + Хитозан II, Хитозан I) отмечали достоверное $(\mathrm{p}<0,05)$ увеличение числа корней пшеницы по сравнению с контролем. При этом препараты не оказывали достоверного влияния на число и длину узловых корней, число колосков в колосе, площадь флагового и предфлагового листьев. В то же время наблюдалось существенное положительное влияние препарата Витаплан, Ж совместно с комплексом Хитозан II на массу колоса пшеницы (увеличение по сравнению с контролем на 65,2 \%, $t=7,2, \mathrm{p}<0,05$ ) (см. рис., Б) и массу вегетативной части растения (на 28,4 \%, $t=2,9, \mathrm{p}<0,05$ ) (см. рис., В). При использовании Хитозана I происходил достоверный рост только массы вегетативной части (на $39,8 \%$, p < 0,05).

На рисунке 1 (Г) представлена нормированная гистограмма с накоплением, отражающая изменение числа положительных и статистически достоверных положительных изменений 14 показателей продуктивности пшеницы при применении биопрепаратов и хитозановых комплексов по сравнению с контролем. Предварительно были отобраны показатели с положительным изменением величины конкретных показателей продуктивности по отношению к значениям в контроле (по вариантам опыта). Далее осуществляли их ранжирование, в том числе с учетом значений $t$-критерия Стьюдента при $\mathrm{p}=0,05$. По биологической эффективности препараты образовали следующий ряд: Витаплан, Ж > Витаплан, Ж + Хитозан II > Гамаир, СП > Хитозан I > Хитозан II.

На основе кластерного анализа (метод k-means) (34) распределили изученные биопрепараты и хитозановые составы в две группы по эффективности действия на пшеницу в соответствии с изменениями средних комплекса показателей относительно контроля. К первой группе были отнесены Гамаир, СП, Витаплан, Ж и Хитозан I, ко второй - Витаплан, Ж + Хитозан II и Хитозан II. Препараты, отнесенные ко второй группе, по сравнению с препаратами первой группы характеризовались более выраженным действием на массу корней (на $12,7 \% ; t=5,8 ; \mathrm{p}<0,05)$, число узловых корней (на $14,7 \% ; t=6,7 ; \mathrm{p}<0,05)$, на длину узловых корней (на $13,0 \% ; t=2,6 ; \mathrm{p}<0,05$ ), площадь флагового листа (на $10,4 \% ; t=4,4$; $\mathrm{p}<0,05$ ), на массу колоса (на $27,1 \% ; t=7,4$; $\mathrm{p}<0,05$ ), массу вегетативной части (на $11,7 \% ; t=4,7 ; \mathrm{p}<0,05)$. Использование препаратов Витаплан, Ж + Хитозан II и Хитозан II приводило к недостоверному замедлению развития растений (на 2,8 \% по фазе онтогенеза), формированию достоверно меньшего числа корней при их меньшей длине (соответственно на $25,7 \% ; t=5,7 ; \mathrm{p}<0,05$ и $11,3 \% ; t=4,4 ; \mathrm{p}<0,05)$.

Методом главных компонент факторного анализа (34) с использованием Варимакс-процедуры вращения осей (Varimax normalized, факторные нагрузки в процедуре нормализуются делением на корень квадратный из соответствующей дисперсии) были оценены взаимосвязи между относительным изменением показателей продуктивности пшеницы, обусловленные влиянием биопрепаратов и хитозановых составов (рис. 2, А). Наиболее выраженным влиянием на продуктивность обладал комплекс Витаплан, Ж + Хитозан II, наименее выраженным - Хитозан II. 
Применение комплекса Хитозан I способствовало увеличению потенциальной урожайности пшеницы на $19,0 \%(t=2,8, \mathrm{p}<0,05)$ по сравнению с контролем (см. рис. 2, Б). Мы не выявили существенных различий в потенциальной урожайности в вариантах с биопрепаратом Витаплан, Ж, комплексом Витаплан, Ж + Хитозан II и Хитозаном II. При использовании биопрепарата Гамаир, СП потенциальная урожайность пшеницы была меньше по сравнению с контролем на $25,0 \%(t=3,5, \mathrm{p}<0,05)$.

A

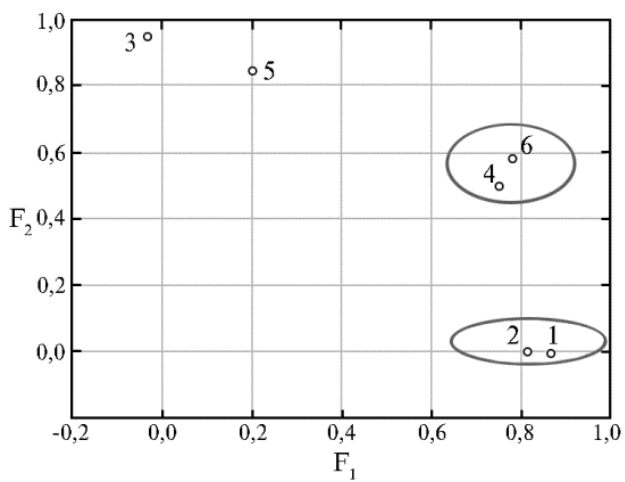

Б

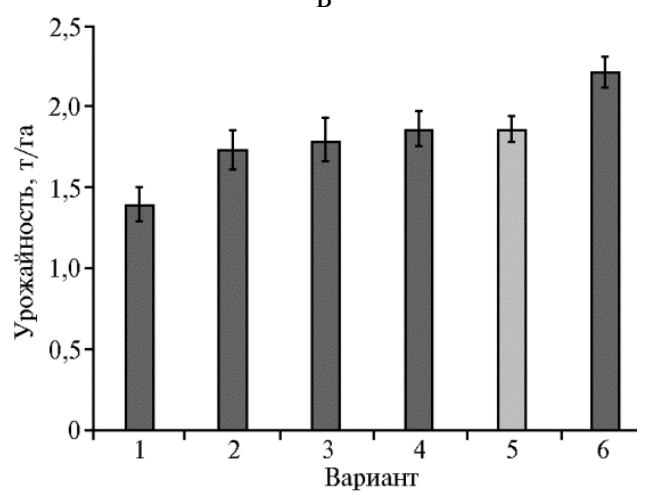

Рис. 2. Факторный анализ (А) и потенциальная урожайность (Б) яровой мягкой пшеницы (Triticum aestivum L.) сорта Ленинградская 6 при обработке растений полифункциональными препаратами на основе штаммов микроорганизмов-антагонистов и хитозановыми комплексами: 1 Гамаир, СП, 2 - Витаплан, Ж + Хитозан II, 3 - Хитозан II, 4 - Витаплан, Ж, 5 - контроль (вода), 6 - Хитозан I (г. Санкт-Петербург-Пушкин, опытное поле, 2016 год).

В 2017 году при пониженных относительно нормы значениях среднемесячной температуры, незначительных осадках (29 \% от нормы мая) и превышении нормы выпавших осадков в летние месяцы максимальный достоверный прирост урожайности $(82,6 \%$, p < 0,05) наблюдался в варианте Витаплан, Ж + Хитозан II (рис. 3). По сравнению с 2016 годом в контрольном варианте этот показатель был достоверно выше на 77,1 \%. В вариантах Витаплан, Ж и Витаплан, Ж + Хитозан II урожайность существенно выросла - соответственно на 2,3 и 4,3 т/га. Незначительные различия по годам наблюдались при использовании комплекса Хитозан II.

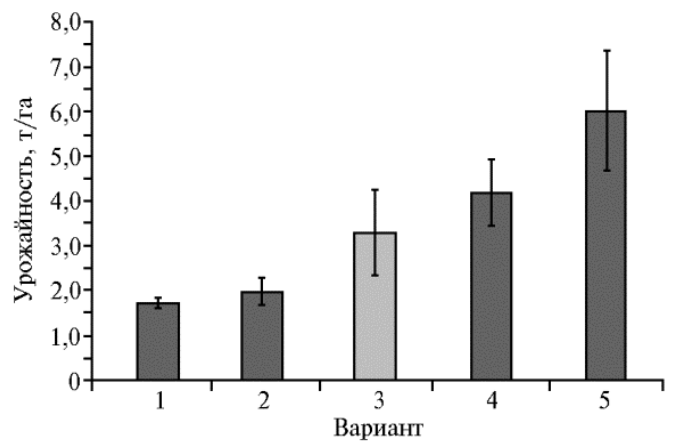

Рис. 3. Потенциальная урожайность яровой мягкой пшеницы (Triticum aestivum L.) сорта Ленинградская 6 при обработке растений полифункциональными препаратами на основе штаммов микроорганизмов-антагонистов и хитозановыми комплексами: 1 - Витаплан, СП, 2 - Хитозан II, 3 - контроль (вода), 4 - Витаплан, Ж, 5 Витаплан, Ж + Хитозан II (г. Санкт-Петербург-Пушкин, опытное поле, 2017 год).

В 2017 году все препараты, за исключением Витаплана, Ж, достоверно $(\mathrm{p}<0,05)$ и положительно повлияли на скорость развития растений по фазам (Витаплан, Ж + Хитозан II - на 25,04 \%; Хитозан II - на 33,59 \%; Витаплан, СП - на 25,58 \%) и их высоту (Витаплан, Ж + Хитозан II - на $32,57 \%$; Хитозан II - на 45,22 \%; Витаплан, СП - на 49,44 \%) по сравнению с контролем (увеличение в среднем соответственно на 10,0 и 16,2 \%). Комплекс Витаплан, Ж + Хитозан II повлиял на увеличение числа колосков в колосе (на 7,66 \% по сравнению с контролем), на продуктивную (на $116,00 \%)$ и общую (на 22,19\%) 
кустистость растений. В этом варианте растения выделялись большей площадью флагового листа (на 86,84 \%) и массой корней (на 83,33 \%).

На рисунке 4 приведено количество положительных (отрицательных) и достоверно положительных (отрицательных) изменений в значениях показателей продуктивности пшеницы при использовании препаратов по сравнению с контролем. По биологической эффективности препараты можно было ранжировать следующим образом: Витаплан, Ж > Витаплан, СП > Витаплан, Ж + Хитозан II > Хитозан II. При этом применение комплекса Витаплан, Ж + Хитозан II обусловливало рост максимального

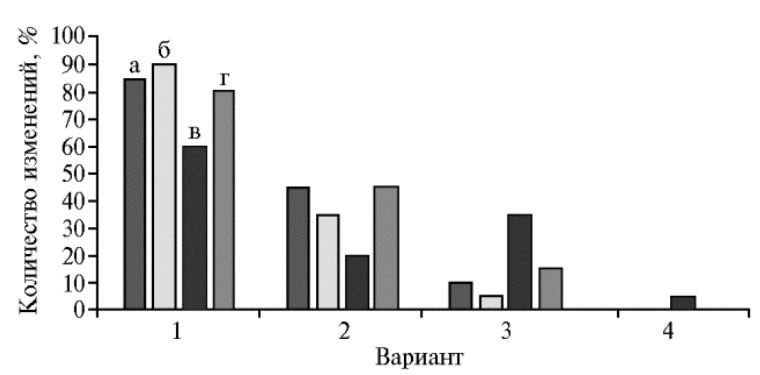

Рис. 4. Количество положительных изменений (1), положительных достоверных измерений (2), отрицательных измерений (3) и отрицательных достоверных измерений (4) по сравнению с контролем в значениях показателей продуктивности у яровой мягкой пшеницы (Triticum aestivum L.) сорта Ленинградская 6 при обработке растений полифункциональными препаратами на основе штаммов микроорганизмов-антагонистов и хитозановыми комплексами: а - Витаплан, Ж, б - Витаплан, Ж + Хитозан II, в - Хитозан II, г - Витаплан, СП (г. СанктПетербург-Пушкин, опытное поле, 2017 год).

тозан II в 2016 году отмечали снижение развития корневой гнили на $80 \%$ по сравнению с контролем, в 2017 году симптомов развития болезни не выявили (рис. 5).

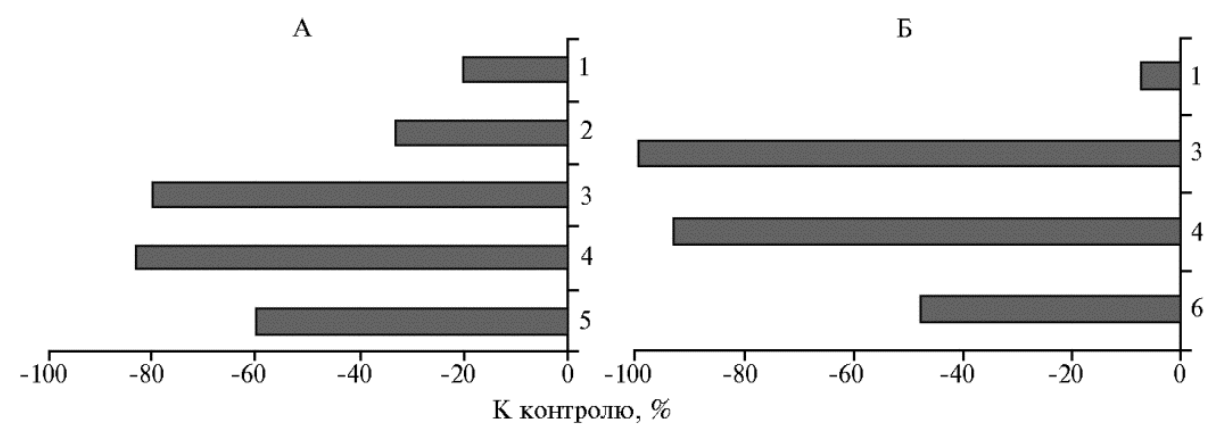

Рис. 5. Интенсивность развития гельминтоспориозной корневой гнили на растениях яровой мягкой пшеницы (Triticum aestivum L.) сорта Ленинградская 6 в 2016 (А) и 2017 годах (Б) при использовании полифункциональных препаратов на основе штаммов микроорганизмов-антагонистов и хитозановых комплексов по сравнению с контролем: 1 - Хитозан II, 2 - Хитозан I, 3 - Витаплан, Ж + Хитозан II, 4 - Витаплан, Ж, 5 - Гамаир, СП, 6 - Витаплан, СП (г. Санкт-Петербург-Пушкин, опытное поле).

Оценка результатов рентгенографии и газоразрядной визуализации при исследовании интроскопических характеристик собранного зерна яровой мягкой пшеницы с использованием непараметрического корреляционного анализа Спирмена показала, что потенциальная урожайность пшеницы $\mathrm{Y}_{3}$ положительно и достоверно $(\mathrm{p}<0,05)$ коррелировала с площадью 
проекции рентгенограмм $\mathrm{S}_{\mathrm{p} .}(r=0,9)$, интегральной яркостью зерен $\mathrm{I}_{3 .}$ инт. $(r=0,8)$ и суммарной интенсивностью их газоразрядного свечения $\mathrm{I}_{\text {грв. }}$ сумм. $(r=0,8)$. Зависимости между этими показателями могут быть описаны уравнениями регрессии $\mathrm{Y}_{3}=29,36-5,04 \mathrm{~S}_{\mathrm{p} .}{ }^{2}+0,23 \mathrm{~S}_{\mathrm{p} .}{ }^{3}\left(\mathrm{r}^{2}=0,8\right)$; $\mathrm{Y}_{3}=-10,46+0,000038 \mathrm{I}_{\text {3. инт. }}{ }^{2}-0,000000000029 \mathrm{I}_{\text {грв. сумм. }}{ }^{3}\left(\mathrm{r}^{2}=0,83\right)$ и $\mathrm{Y}_{3}=-17,68+37,82 \mathrm{I}_{\text {грв. сумм. }}{ }^{2}+18,09 \mathrm{I}_{\text {грв. сумм. }}{ }^{3}\left(\mathrm{r}^{2}=0,89\right)$. Значения массы 1000 зерен $\mathrm{M}_{1000}$ положительно коррелировали с интегральной яркостью зерен $\mathrm{I}_{\text {3. инт. }}: \mathrm{M}_{1000}=-1,99+0,000042 \mathrm{I}_{3 \text {. инт. }}\left(\mathrm{r}^{2}=0,9\right)$.

По результатам микрофокусной рентгенографии в варианте опыта, где был применен состав Хитозан I, зерна пшеницы имели наилучшие морфометрические и денситометрические характеристики по сравнению с контролем: существенно бо́льшую площадь проекции рентгенограмм (на $9,26 \%, t=2,5$ ), длину (на 3,90 \%,t=2,5) и ширину (на 5,84 \%,t=2,3), увеличенный периметр (на $4,00 \%, t=2,4)$ и средний размер (на $4,50 \%, t=2,7$ ), бо́льшую среднюю яркость свечения (на $5,76 \%, t=3,5$ ) и достоверно меньшие значения оптической плотности (на $3,80 \%, t=3,5)$. То есть обработка растений пшеницы составом Хитозан I привела не только к увеличению размера семян, но и повысила их выполненность (плотность эндосперма). По сравнению с контролем большей средней яркостью рентгенограмм выделялись зерна, полученные при применении комплекса Витаплан, Ж + Хитозан II (на 6,00 \%, $t=4,3$ ), состава Хитозан I (на 5,76 \%, $t=3,5$ ) и Хитозан II (на 9,93 \%, $t=5,4)$. Наибольшей максимальной яркостью отличались зерна, полученные в вариантах опыта с хитозановым составом Хитозан I (на $6,4 \%, t=2,5)$ и Хитозан II (на $10,2 \%, t=3,6$ ). Меньшей средней яркостью рентгенограмм по сравнению с контролем (на $7,6 \%, t=2,7)$ характеризовались зерна, полученные при использовании препарата Гамаир, СП. В варианте с Хитозаном II зерна имели менышие значения фактора круга (на $3,70 \%, t=3,0)$, округлости (на 7,22 \%, $t=2,9)$ и бо́льшую удлиненность (на $4,90 \%, t=2,2$ ) по сравнению с контролем.

В варианте с применением состава Хитозан II газоразрядные характеристики зерна пшеницы существенно различались с контролем по показателю коэффициент формы, характеризующему изрезанность контура газоразрядного изображения и связанному с массой зерен (больше на $23,1 \%, t=2,4)$. При использовании состава Хитозан I зерна имели бо́льшие значения фрактальности по изолинии и бо́льшую длину изолинии газоразрядного изображения по сравнению с контролем (соответственно на $2,8 \%, t=3,8$ и на 20,9\%, $t=2,2$ ). Эти параметры, предположительно, также связаны с размерными характеристиками зерен. В вариантах опыта Витаплан, Ж + Хитозан II и Хитозан II суммарная интенсивность газоразрядного изображения зерна была существенно меньше по сравнению с контролем (соответственно на 19,3\%,t=4,1 и 15,9\%, $t=3,1$ ). Снижение интенсивности газоразрядного свечения характерно для зерен, имеющих лучшие ростовые показатели при проращивании.

Результаты микрофокусной рентгенографии и газоразрядной визуализации показали, что по сравнению с контролем интроскопические показатели зерен в наибольшей степени были изменены в вариантах Хитозан I, Витаплан, Ж + Хитозан II, Хитозан II. Обработка пшеницы только биопрепаратом Витаплан, Ж не оказала влияние на интроскопические характеристики зерен. При использовании биопрепарата Гамаир, СП (стандарт) интроскопические характеристики зерен изменялись незначительно.

Как упоминалось выше, в связи с переходом к биологическому земледелию в последнее время исследователи уделяют особое внимание разработке альтернативных методов защиты растений. Существует не- 
сколько антагонистических микроорганизмов, которые эффективны в отношении широкого спектра возбудителей болезней растений: Pseudomonas fluorescens PCL1751 и P. putida PCL1760 (35), Bacillus spp. (5, 36, 37), а также виды рода Trichoderma $(5,38)$. В целом их целесообразно применять на практике как полноценную альтернативу синтетическим химическим фунгицидам. Однако зачастую эффективность биопрепаратов на основе микробов-антагонистов оказывается недостаточной.

Другим способом контроля заболеваний может быть повышение естественной устойчивости растений к патогену. Соединения, которые запускают собственные защитные механизмы растений, называются индукторами устойчивости. Среди них особое место принадлежит хитозану и его производным. Биологическая активность хитозана связана с его способностью индуцировать защитные реакции фитоиммунитета $(39,40)$. Содержание хитозана в клеточных стенках некоторых микроорганизмов, в частности фитопатогенных грибов, обусловливает важнейшее свойство этого полимера как молекулярного паттерна PAMPs (pathogen-associated molecular pattern), который распознается белковыми рецепторами растений (pattern recognition receptors, PRR). В результате происходит активация комплекса защитных реакций неспецифического иммунитета растения (patterntriggered immunity, PTI), включая синтез фитоалексинов, лигнификацию клеточных стенок, отложение каллозы, синтез PR-белков, генерацию активных форм кислорода (АФК) и азота (NO) и т.д. (41).

С целью возможного повышения защитного эффекта микробных антагонистов многими учеными ведутся исследования совместного применения биоагента и индуктора устойчивости. Так, M. Rajkumar c coaвт. (42) показали, что эффективность флуоресцентных псевдомонад Pseudomonas fluorescens (штаммы SE21 и RD41) при контроле ризоктониоза перца может стимулироваться хитином. Добавление хитина повышает защиту растений, стимулируя выработку родственных метаболитов, которые способствуют антагонистической активности и/или стимулируют защитные свойства растений. Обработка вегетирующих растений перца, огурца, томатов Saccharomyces cerevisiae совместно с хитозаном снижала развитие ложной мучнистой росы в 2 раза и более (43). В работе R.S. Niranjan c соавт. (44) приведены результаты испытания составов, включающих два штамма Bacillus с хитозаном в качестве носителя, установлена их способность стимулировать рост и повышать устойчивость проса к ложной мучнистой росе. Наиболее эффективным оказался способ применения составов, сочетающий внесение в почву хитозана с обработкой семян штаммами микробов-антагонистов (45). Таким образом, индукторы устойчивости в комбинации с биоактивными веществами имеют широкие перспективы для будущего использования антагонистических микроорганизмов в борьбе с болезнями растений, особенно в условиях защищенного грунта (46). Интерес представляют композиции микробов-антагонистов, например из рода Bacillus, с хитозаном и его производными.

Основная проблема оценки эффективности обработки растений на качество семенного и продовольственного зерна - количественная объективизация стимулирующего действия. Одним из ее решений может стать разработка и применение современной интроскопической аппаратуры и информационных средств экспресс-диагностики скрытой неоднородности зерна. Параметры прорастания тесно связаны с морфометрическими показателями семян, которые могут определяться с помощью рентгенографического анализа: в лабораторных условиях крупные семена прорастают раньше и лучше, чем мелкие (47). Сообщалось (48), что оптические харак- 
теристики рентгенограмм важны для обеспечения качества семян. Параметр относительной оптической плотности позволяет делать выводы относительно плотности внутренних тканей семян и, следовательно, их физиологического качества (49).

Следует отметить, что эффективность полифункционального препарата Витаплан, Ж + Хитозан II в отношении потенциальной урожайности пшеницы в наибольшей степени определялась его влиянием на продуктивную кустистость, что может быть связано с более развитой корневой системой растений (по числу и длине корней) и выраженным снижением интенсивности поражения корневой системы гельминтоспориозной корневой гнилью при применении этого препарата по сравнению с другими вариантами опыта. Кроме того, при использовании комплекса Витаплан, Ж + Хитозан II выявлено более быстрое прохождение растениями фаз онтогенеза.

Итак, проведенные исследования убедительно показали перспективность использования полифункциональных препаратов, объединяющих полезные свойства штаммов микроорганизмов - антагонистов возбудителей болезней и активатора болезнеустойчивости растений - хитозана, для защиты пшеницы от корневой гнили, повышения урожайности и улучшения качества зерна. На основании достоверных положительных изменений показателей продуктивности биопрепараты были ранжированы следующим образом: в 2016 году - Витаплан, Ж > Витаплан, Ж + Хитозан II > Гамаир, CП > Хитозан I > Хитозан II; в 2017 году - Витаплан, Ж > Витаплан, СП > Витаплан, Ж + Хитозан II > Хитозан II. При совместном применении препарата Витаплан, Ж с хитозановым комплексом Хитозан II в 2016 году в более благоприятных для роста растений погодных условиях (повышенные значения температуры и увеличение количества выпавших осадков) отмечено достоверное изменение не только массы вегетативной части растения, но и массы колоса, в то время как при использовании комплекса Хитозан II достоверно увеличивалась только масса вегетативной части растений. В 2017 году (при пониженной среднемесячной температуре и значительном количестве осадков) в этом варианте растения выделялись площадью флагового листа и массой корней (больше соответственно на 86,84 и 83,33 \% по сравнению с контролем). В 2016 году применение Хитозана I способствовало достоверному увеличению потенциальной урожайности пшеницы на $19,0 \%(t=3,0 ; \mathrm{p}<0,05)$ по сравнению с контролем, однако не было выявлено существенных различий в вариантах с биопрепаратом Витаплан, Ж, комплексом Витаплан, Ж + Хитозан II, составом Хитозан II. В 2017 году наибольший достоверный прирост урожайности $82,6 \%(t=7,2 ; \mathrm{p}<0,05)$, напротив, был зарегистрирован в варианте Витаплан, Ж + Хитозан II. Максимальной эффективностью в отношении гельминтоспориозной корневой гнили обладали биопрепарат Витаплан, Ж и комплекс Витаплан, Ж + Хитозан II. В варианте Витаплан, Ж + Хитозан II в 2016 году отмечено снижение развития корневой гнили на $80 \%$ по сравнению с контролем, а в 2017 году симптомов развития болезни не выявляли. Возможно, это обусловлено менее благоприятными для развития корневой гнили метеоусловиями 2017 года по сравнению с 2016 годом (в частности, пониженными среднемесячными температурами и значительной суммой осадков за летний период). Потенциальная урожайность пшеницы достоверно положительно коррелировала с площадью проекции рентгенограммы, интегральной яркостью зерен и суммарной интенсивностью газоразрядного свечения. В наибольшей степени на структурно-функциональные характеристики зерна оказывали влияли составы Хитозан I, Хи- 


\author{
${ }_{1}^{1}$ ФББОУ ВО Санкт-Петербургский государственный \\ аграрный университет, \\ 196601 Россия, г. Санкт-Петербург-Пушкин, Петербургское ш., 2, \\ e-mail: kleon9@yandex.ru $\bowtie$, nastasya115@mail.ru; \\ 2ФГБНУ Всероссийский НИИ защиты растений, \\ 196608 Россия, г. Санкт-Петербург-Пушкин, ш. Подбельского, 3, \\ e-mail: elzavpopova@mail.ru, irina novikova@inbox.ru; \\ ЗФГБНУ Агрофизический научно-исследовательский \\ институт, \\ 195220 Россия, г. Санкт-Петербург, Гражданский просп., 14, \\ e-mail: prini@mail.ru, agrorentgen@mail.ru; \\ ${ }_{4}^{4}$ ФББНУ ФИЦ Всероссийский институт генетических \\ ресурсов растений им. Н.И. Вавилова, \\ 190000 Россия, г. Санкт-Петербург, ул. Большая Морская, 42-44, \\ e-mail: jusab@yandex.ru; \\ 5 ФГАОУ ВО Санкт-Петербургский государственный \\ электротехнический университет «ЛЭТИ» \\ им. В.И. Ульянова (Ленина), \\ 197376 Россия, г. Санкт-Петербург, ул. Профессора Попова, 5, \\ e-mail: kzhamova@gmail.com; \\ ${ }^{6}$ Institute of Biology Leiden, PBDL, Leiden University, \\ and Fytagoras BV: Sylvius Laboratory, \\ Sylviusweg 72, 2333 BE Leiden, The Netherlands, \\ e-mail: a.van.duijn@biology.leidenuniv.nl, bert.vanduijn@fytagoras.com
}

Поступила в редакцию 8 июня 2019 года

Sel'skokhozyaistvennaya biologiya [Agricultural Biology], 2019, V. 54, № 5, pp. 1024-1040

\title{
MULTIFUNCTIONAL BIOLOGICS WHICH COMBINE MICROBIAL ANTI-FUNGAL STRAINS WITH CHITOSAN IMPROVE SOFT WHEAT (Triticum aestivum L.) YIELD AND GRAIN QUALITY
}

\author{
L.E. Kolesnikov', E.V. Popova ${ }^{2}$, I.I. Novikova' ${ }^{2}$, N.S. Priyatkin ${ }^{3}$, M.V. Arkhipov³, \\ Yu.R. Kolesnikova ${ }^{4}$, N.N. Potrakhov' ${ }^{5}$ B. van Duijn' 6 , A.S. Gusarenko'
}

\begin{abstract}
${ }^{1}$ Saint-Petersburg State Agrarian University, 2, Peterburgskoe sh., St. Petersburg-Pushkin, 196601 Russia, e-mail kleon9@yandex.ru ( $\square$ corresponding author), nastasya115@mail.ru;

${ }^{2}$ All-Russian Research Institute of Plant Protection, 3, sh. Podbel'skogo, St. Petersburg, 196608 Russia, e-mail elzavpopova@mail.ru, irina_novikova@inbox.ru;

${ }^{3}$ Agrophysical Research Institute, 14, Grazhdanskii prosp., St. Petersburg, 195220 Russia, e-mail prini@mail.ru, agrorentgen@mail.ru;

${ }^{4}$ Federal Research Center Vavilov All-Russian Institute of Plant Genetic Resources, 42-44, ul. Bol'shaya Morskaya, St. Petersburg, 190000 Russia, e-mail jusab@yandex.ru;

${ }^{5}$ Saint Petersburg Electrotechnical University LETI, 5, ul. Professora Popova St. Petersburg, 197376 Russia, e-mail kzhamova@gmail.com;

${ }^{6}$ Institute of Biology Leiden, PBDL, Leiden University, and Fytagoras BV: Sylvius Laboratory, Sylviusweg 72, 2333 BE Leiden, The Netherlands, e-mail a.van.duijn@biology.leidenuniv.nl, bert.vanduijn@fytagoras.com
\end{abstract}

ORCID:

Kolesnikov L.E. orcid.org/0000-0003-3765-1192

Popova E.V. orcid.org/0000-0003-3165-6777

Novikova I.I. orcid.org/0000-0003-2816-2151

Priyatkin N.S. orcid.org/0000-0002-5974-4288

Arkhipov M.V. orcid.org/0000-0002-6903-6971

The authors declare no conflict of interests

Received June 8, 2019

\author{
Kolesnikova Yu.R. orcid.org/000-0002-4002-220X \\ Potrakhov N.N. orcid.org/0000-0001-8806-0603 \\ van Duijn B. orcid.org/0000-0003-0304-5485 \\ Gusarenko A.S. orcid.org/0000-0001-7027-9009
}

doi: 10.15389/agrobiology.2019.5.1024eng

\section{Abstract}

The developing of effective and high-tech preparations for microbiological plant protection is a crucial problem of agricultural biotechnology. In this paper, we revealed differences in the crop structure, grain introscopic characteristics and resistance of soft wheat plants to root rot when using novel multifunctional bioactive preparations. Our objective was to investigate effects of developed bioactive compositions based on microbial antagonists of plant pathogenic and chitosan complexes on spring soft wheat (Triticum aestivum L.) variety Leningradskaya 6. Plant protection against root rot, productivity and grain quality assessed by the methods of microfocus X-ray radiography and gasdischarge visualization were estimated in two-year field tests (Leningrad Province, 2016-2017). The weather conditions during growing season of 2016 were more favorable for wheat plants compared to 2017 due to a slight temperature fluctuation and a significant amount of precipitation. The number 
of spikelets per spike, flag and pre-flag leaf area, the weight of spike and vegetative parts were the indicators for wheat productivity, germination energy, seedling length, dynamics of plant growth phase and height, the number, length and weight of roots. According to significant positive influence of the studied compositions on yield structure, the biopreparations rank as follows: in 2016 - Vitaplan, Zh (OOO AgroBioTekhnologiya, Russia) > Vitaplan, Zh + Chitosan II (test preparation containing 50 and $100 \mathrm{kDa}$ chitosans with the addition of $0.1 \%$ vanillin, FSBSI VIZR) $>$ Gamair, SP (OOO AgroBioTekhnologiya, Russia) > Chitosan I (test preparation containing 50 and $100 \mathrm{kDa}$ chitosans with the addition of $0.05 \%$ salicylic acid, FSBSI VIZR) > Chitosan II; in 2017 - Vitaplan, Zh > Vitaplan, SP > Vitaplan, Zh + Chitosan II > Gamair, SP > Chitosan II. In 2016, a combined use of Vitaplan, $\mathrm{Zh}$ and Chitosan II changed significantly not only the plant vegetative part weight, but also the spike weight, while separate use of Chitosan II significantly increased the vegetative biomass only. In 2017, the same combination of the biologicals made the flag leaf $86.84 \%$ larger and the root weight $83.33 \%$ higher compared to the control. In 2016, Chitosan I led to reliable $19.0 \%$ increase $(t=3,0 ; \mathrm{p}<0.05)$ in potential grain yield compared to the control, however, there were no significant differences for Vitaplan, $\mathrm{Zh}$, Chitosan II and their combination Vitaplan, Zh + Chitosan II. On the contrary, in 2017 Vitaplan, Zh + Chitosan II caused the maximum reliable $(t=7.2 ; \mathrm{p}<0.05)$ increase in yield (by $82.6 \%)$. Vitaplan, $\mathrm{Zh}$ and Vitaplan, $\mathrm{Zh}+\mathrm{Chi}-$ tosan II possess maximum efficiency against Helminthosporium root rot. Due to Vitaplan, $\mathrm{Zh}+\mathrm{Chi}-$ tosan II, in 2016 root rot disease frequency was $80 \%$ lower compared to the control, and in 2017 no symptoms were observed which may be due to less favorable weather conditions for root rot disease in 2017 compared to 2016. According to our findings, the potential grain yield in wheat correlates significantly and positively with grain $\mathrm{X}$-radiographic projection area, integrated grain brightness and total intensity of the gas-discharge fluorescence. Chitosan I, Chitosan II and Vitaplan, F + Chitosan II have the greatest impact on grain structure and quality parameters assessed by X-ray and gasdischarge visualization. Perhaps the effectiveness of the studied drugs depended on weather conditions, but was generally positive in terms of the main assessed indicators. Thus, our data convincingly indicate the effectiveness of multifunctional biologics which combine microbial antagonists of fungal plant pathogens with chitosan, an activator of plant diseases resistance, to protect wheat against root rot, to increase grain yield with better quality.

Keywords: Triticum aestivum L., spring soft wheat, biological preparations, chitosan composition, yield structure, root rot, grain quality, microsofus X-ray, gas discharge visualization.

\section{REFEREN CES}

1. Lichko N.M., Kolomiets S.N. Zernovoe khozyaistvo, 2007, 7: 12-14 (in Russ.).

2. Petrov N.Yu., Bilous V.V., Kalmykova E.V. Izvestiya Nizhnevolzhskogo agrouniversitetskogo kompleksa, 2010, 2(18): 55-58 (in Russ.).

3. Novikova I.I. Biologicheskoe obosnovanie sozdaniya i primeneniya polifunktsional'nykh biopreparatov na osnove mikrobov-antagonistov dlya fitosanitarnoi optimizatsii agroekosistem. Avtoreferat doktorskoi dissertatsii [Biological aspects of creation and use of multifunctional biological products based on antagonist microbes for phytosanitary optimization of agroecosystems. PhD Thesis]. St. Petersburg, 2005 (in Russ.).

4. Novikova I.I. Materialy 3-go Vserossiiskogo s"ezda po zashchite rastenii "Fitosanitarnaya optimizatsiya agroekosistem» [Proc. 3rd All-Russian Congress on plant protection «Phytosanitary optimization of agroecosystems»]. St. Petersburg, 2013: 372-378 (in Russ.).

5. Novikova I.I., Litvinenko A.I. Vestnik zashchity rastenii, 2011, 2: 5-12 (in Russ.).

6. Deepmala K., Hemantaranjan A., Bharti S., Nishant Bhanu A. A future perspective in crop protection: chitosan and its oligosaccharides. Adv. Plants Agric. Res., 2014, 1(1): 23-30 (doi: 10.15406/apar.2014.01.00006).

7. Malerba M., Cerana R. Recent applications of chitin- and chitosan-based polymers in plants. Polymers, 2019, 11(5): 839 (doi: 10.3390/polym11050839).

8. Vasconcelos M.W. Chitosan and chitooligosaccharide utilization in phytoremediation and biofortification programs: current knowledge and future perspectives. Frontiers in Plant Science, 2014, 5: 616 (doi: 10.3389/fpls.2014.00616).

9. Tyuterev S.L. Prirodnye $i$ sinteticheskie induktory ustoichivosti rastenii $k$ boleznyam [Natural and synthetic inducers of plant resistance to diseases]. St. Petersburg, 2014 (in Russ.).

10. Tyuterev S.L. Vestnik zashchity rastenii, 2015, 1(83): 3-13 (in Russ.).

11. Starikova D.V. Politematicheskii setevoi elektronnyi nauchnyi zhurnal Kubanskogo gosudarstvennogo agrarnogo universiteta, 2014, 98: 1-13 (in Russ.).

12. Zimoglyadova T.V., Zhadan V.V., Nakaznoi S.V. Zashchita i karantin rastenii, 2009, 11: 25-26 (in Russ.).

13. Boonsongrit Y., Mitrevej A., Mueller B.W. Chitosan drug binding by ionic interaction. European Journal of Pharmaceutics and Biopharmaceutics, 2006, 62(3): 267-274 (doi: 10.1016/j.ejpb.2005.09.002). 
14. Wanichpongpan P., Suriyachan K., Chandrkrachang S. Effects of chitosan on the growth of gerbera flower plant (Gerbera jamesonii). In: Chitin and chitosan in life science. Proceedings of the eighth International chitin and chitosan conference and fourth Asia Pacific chitin and chitosan symposium. T. Uragami, K. Kurita, T. Fukamizo (eds.). Japan, Yamaguchi, 2001: 198-201.

15. Bhaskara R.M.V., Arul J., Angers P., Couture L. Chitosan treatment of wheat seeds induces resistance to Fusarium graminearum and improves seed quality. Journal of Agricultural and Food Chemistry, 1999, 47(3): 1208-1216 (doi: 10.1021/jf981225k).

16. Orzali L., Forni C., Riccioni L. Effect of chitosan seed treatment as elicitor of resistance to Fusarium graminearum in wheat. Seed Science and Technology, 2014, 42(2): 132-149(18) (doi: 10.15258/sst.2014.42.2.03).

17. Zeng D., Luo X. Physiological effects of chitosan coating on wheat growth and activities of protective enzyme with drought tolerance. Open Journal of Soil Science, 2012, 2(3): 282-288 (doi: 10.4236/ojss.2012.23034).

18. Pavlyushin V.A., Tyuterev S.L., Popova E.V., Novikova I.I., Boikova I.V., Bykova G.A. Materialy mezhdunaroinoi konferentsii «Sovremennye perspektivy $v$ issledovanii khitina» [Proc. Int. Conf. «Chitin - current prospects and investigations»]. Murmansk, 2012: 398-404 (in Russ.).

19. Pavlyushin V.A., Tyuterev S.L., Popova E.V., Novikova I.I., Bykova G.A., Domnina N.S. Biotekhnologiya, 2010, 4: 69-80 (in Russ.).

20. Meleshkina E.P. Agrarnyi vestnik Yugo-Vostoka, 2009, 3: 4-7 (in Russ.).

21. Arkhipov M.V., Potrakhov N.N. Mikrofokusnaya rentgenografiya rastenii [Microfocus radiography of plants]. St. Petersburg, 2008 (in Russ.).

22. Musaev F.B., Kurbakova O.V., Kurbakov E.L., Arkhipov M.V., Velikanov L.P., Potrakhov N.N. Gavrish, 2011, 1: 44-46 (in Russ.).

23. van der Burg W.J., Jalink H., van Zwol R.A., Aartse J.W., Bino R.J. Non-destructive seed evaluation with impact measurements and X-ray analysis. Acta Horticulturae, 1995, 362: 149-157 (doi: 10.17660/ActaHortic.1994.362.18).

24. de Carvalho M.L.M., van Aelst A.C., van Eck J.W., Hoekstra F.A. Pre-harvest stress cracks in maize (Zea mays L.) kernels as characterized by visual, X-ray and low temperature scanning electron microscopical analysis: effect on kernel quality. Seed Science Research, 1999, 9: 227236 (doi: 10.1017/S0960258599000239).

25. Gomes-Junior F.G., Yagushi J.T., Belini U.L., Cicero S.M., Tomazello-Filho M. X-ray densitometry to assess internal seed morphology and quality. Seed Science and Technology, 2012, 40(1): 102-107 (doi: 10.15258/sst.2012.40.1.11)

26. Silva V.N., Cicero S.M., Bennett M. Associations between X-ray visualised internal tomato seed morphology and germination. Seed Science and Technology, 2013, 41(2): 225-234 (doi: 10.15258/sst.2013.41.2.05).

27. Del Nobile M.A., Laverse J., Lampignano V., Cafarelli B., Spada A. Applications of tomography in food inspection. In: Industrial Tomography: Systems and applications. Woodhead Publishing, 2015: 693-712 (doi: 10.1016/B978-1-78242-118-4.00025-3).

28. Arkhipov M.V., Priyatkin N.S., Gusakova L.P., Kulkov A.M. Visualization of internal structural defects of wheat seeds using microCT. MicroCT User Meeting. Abstract Book. Bruge, Belgium, 2015: 177-179.

29. Lu M., Zhang Y., Sun J., Chen S., Li N., Zhao G., Shen J. Identification of maize seeds by terahertz scanning imaging. Chinese Optics Letters, 2005, 3(51): 239-241.

30. Ge H., Jiang Y., Xu Z., Lian F., Zhang Y., Xia S. Identification of wheat quality using $\mathrm{THz}$ spectrum. Optics Express, 2014, 22(10): 12533-12544 (doi: 10.1364/OE.22.012533).

31. Jiang Y., Ge H., Lian F., Zhang Y., Xia S. Early detection of germinated wheat grains using terahertz image and chemometrics. Scientific Reports, 2016, 6: 21299 (doi: 10.1038/srep21299).

32. Merezhko A.F., Udachin R.A., Zuev V.E., Filotenko A.A., Serbin A.A., Lyapunova O.A., Kosov V.Yu., Kurkiev U.K., Okhotnikova T.V., Navruzbekov N.A., Boguslavskii R.L., Abdullaeva A.K., Chikida N.N., Mitrofanova O.P., Potokina S.A. Popolnenie, sokhranenie $v$ zhivom vide $i$ izuchenie mirovoi kollektsii pshenitsy, egilopsa i triticale [Replenishment, living form preservation and study of the world collection of wheat, aegilops and triticale plants]. St. Petersburg, 1999: 3235 (in Russ.).

33. Popov Yu.V. Zashchita i karantin rastenii, 2011, 8: 45-47 (in Russ.).

34. Nasledov A.D. IBM SPSS Statistics 20 i AMOS: professional'nyi statisticheskii analiz dannykh [IBM SPSS Statistics 20 and AMOS: Professional statistical data analysis]. St. Petersburg, 2013 (in Russ.).

35. Kamilova F., Validov S., Lugtenberg B. Biological control of tomato foot and root rot caused by Fusarium oxysporum f. sp. radicis-lycopersici by Pseudomonas bacteria. Acta Horticulturae, 2009, 808: 317-320 (doi: 10.17660/ActaHortic.2009.808.50).

36. Sharifi Tehrani A., Ramezani M. Biological control of Fusarium oxysporum, the causal agent of onion wilt by antagonistic bacteria. Commun. Agric. Appl. Biol. Sci., 2003, 68(4 Pt B): 543-547.

37. Schisler D.A., Slininger P.J., Behle R.W., Jackson M.A. Formulation of Bacillus spp. for biological control of plant diseases. Phytopathology, 2004, 94(11): 1267-1271 (doi: 
10.1094/PHYTO.2004.94.11.1267).

38. Abdel-Kader M.M., El-Mougy N.S., Aly M.D.E., Lashin S.M., Abdel-Kareem F. Greenhouse biological approach for controlling foliar diseases of some vegetables. Advances in Life Sciences, 2012, 2(4): 98-103 (doi: 10.5923/j.als.20120204.03).

39. Badawy M.E.J., Rabea E.I. A biopolymer chitosan and its derivatives as promising antimicrobial agents against plant pathogenes and their applications in crop protection. International Journal of Carbohydrate Chemistry, 2011: Article ID 460381 (doi: 10.1155/2011/460381).

40. El Hadrami A., Adam L.R., El Hadrami I., Daayf F. Chitosan in plant protection. Marine Drugs, 2010, 8(4): 968-987 (doi: 10.3390/md8040968).

41. Iriti M., Faoro F. Chitosan as a MAMP, searching for a PRR. Plant Signaling \& Behavior, 2009, 4(1): 66-68 (doi: 10.4161/psb.4.1.7408).

42. Rajkumar M., Lee K.J., Freitas H. Effects of chitin and salicylic acid on biological control activity of Pseudomonas spp. against damping off of pepper. South African Journal of Botany, 2008, 74(2): 268-273 (doi: 10.1016/j.sajb.2007.11.014).

43. Abdel-Kader M.M., El-Mougy N.S., Aly M.D.E., Lashin S.M. Integration of biological and fungicidal alternatives for controlling foliar diseases of vegetables under greenhouse conditions. International Journal of Agriculture and Forestry, 2012, 2(2): 38-48 (doi: 10.5923/j.ijaf.20120202.07).

44. Niranjan R.S., Deepak S.A., Basavaraju P., Shetty H.S., Reddy M.S., Kloepper J.W. Comparative performance of formulations of plant growth promoting rhizobacteria in growth promotion and suppression of downy mildew in pearl millet. Crop Protection, 2003, 22(4): 579-588 (doi: 10.1016/S0261-2194(02)00222-3).

45. Algam S.A.E., Xie G., Li B., Yu S., Su T., Larsen J. Effects of Paenibacillus strains and chitosan on plant growth promotion and control of Ralstonia wilt in tomato. Journal of Plant Pathology, 2010, 92(3), 593-600.

46. Abdel-Kader M.M., El-Mougy N.S., Lashin S.M. Biological and chemical resistance inducers approaches for controlling foliar diseases of some vegetables under protected cultivation system. J. Plant Pathol. Microb., 2013, 4: 200 (doi: 10.4172/2157-7471.1000200).

47. Cicek E., Tilki F. Seed size effects on germination, survival and seedling growth of Castanea sativa Mill. Journal of Biological Sciences, 2007, 7(2): 438-441 (doi: 10.3923/jbs.2007.438.441).

48. Huang M., Wang Q.G., Zhu Q.B., Qin J.W., Huang G. Review of seed quality and safety tests using optical sensing technologies. Seed Science and Technology, 2015, 43(3): 337-366 (doi: 10.15258/sst.2015.43.3.16).

49. Abud H.F., Cicero S.M., Gomes Junior F.G. Radiographic images and relationship of the internal morphology and physiological potential of broccoli seeds. Acta Scientiarum. Agronomy, 2018, 40(1): e34950 (doi: 10.4025/actasciagron.v40i1.34950). 